\title{
Company Profile KPKNL Batam dalam Bentuk Video
}

\author{
Try Widya Hastuti ${ }^{1}$, Evaliata Br Sembiring ${ }^{2}$ \\ Program Studi Teknik Multimedia dan Jaringan, Jurusan Teknik Informatika, Politeknik Negeri Batam \\ $\underline{\text { trywidya37@gmail.com }}^{1}$, eva@polibatam.ac.id ${ }^{2}$
}

\begin{tabular}{|c|c|}
\hline Article Info & ABSTRAK \\
\hline $\begin{array}{l}\text { Kata Kunci: } \\
\text { Video, } \\
\text { Company profile, } \\
\text { Luther Sutopo, } \\
\text { Quasi Experimental, } \\
\text { Nonequivalent Control Group } \\
\text { Design, } \\
\text { Uji -t. }\end{array}$ & $\begin{array}{l}\text { Informasi tentang layanan KPKNL Batam perlu diketahui oleh masyarakat } \\
\text { terutama pemangku kepentingan. Media informasi saat ini adalah brosur, buku } \\
\text { profil, banner, situs dan media sosial. Namun, memiliki kekurangan terutama } \\
\text { informasi tentang tugas, fungsi dan layanan KPKNL Batam seperti lelang dan } \\
\text { penyewaan asset BMN. Solusi yang ditawarkan adalah video company profile. } \\
\text { Metode penelitian menggunakan R \& D yaitu pembuatan video menggunakan } \\
\text { pendekatan Luther-Sutopo dan analisis kelayakan sebagai media informasi } \\
\text { berdasarkan kualitas video melalui aspek visual dan suara menggunakan skala } \\
\text { Likert. Sementara analisis keefektifan video sebagai media informasi } \\
\text { berdasarkan materi menggunakan pendekatan Quasi Experimental model } \\
\text { Nonequivalent Group Design dengan pengolahan data uji-t. Hasil penelitian } \\
\text { yaitu: (1)Video Company Profile berdurasi } 3 \text { menit } 50 \text { detik dalam format } \\
\text { MP4, dapat dijalankan dalam berbagai perangkat serta dapat diakses secara } \\
\text { online di media sosial KPKNL Batam; (2)Video memiliki kualitas yang baik } \\
\text { berdasarkan pencapaian persentase 98,80\%, sehingga layak memberikan } \\
\text { informasi; (3)Video dinilai efektif sebagai media informasi berdasarkan aspek } \\
\text { konten tentang layanan KPKNL Batam bagi pemangku kepentingan melalui } \\
\text { hasil uji-t kelompok eksperimen dengan nilai Sig. sebesar } 0,000<0,05 \text { nilai } \\
\text { probabilitas; (4)Produksi video dapat dipengaruhi oleh perangkat, sehingga } \\
\text { direkomendasikan untuk mengemas informasi dan layanan yang lebih spesifik } \\
\text { dan rinci di KPKNL Batam. }\end{array}$ \\
\hline
\end{tabular}

Copyright $(0) 2020$ Institute of Advanced Engineering and Science. All rights reserved.

\section{Corresponding Author:}

Second Author,

Teknik Multimedia Jaringan, Jurusan Teknik Informatika,

Politeknik Negeri Batam

Batam Centre, Jl. Ahmad Yani, Tlk. Tering, Kec. Batam Kota, Kepulauan Riau 29461

Email: eva@polibatam.ac.id 


\section{PENDAHULUAN}

Kantor Pelayanan Kekayaan Negara dan Lelang (KPKNL) Batam merupakan instansi vertikal Direktorat Jenderal Kekayaan Negara, Kementerian Keuangan yang berada di bawah Kantor Wilayah DJKN Riau, Sumatera Barat dan Kepulauan Riau. KPKNL Batam memiliki tugas dan fungsi layanan yang beragam, diantaranya pengelolaan kekayaan negara, penilaian, lelang dan piutang negara. Disamping empat layanan tersebut, KPKNL Batam memiliki seksi atau unit pendukung yaitu subbagian umum, hukum dan informasi, kepatuhan internal serta kelompok jabatan fungsional. Instansi ini tidak hanya melayani satuan kerja pemerintah melainkan juga masyarakat umum. Selama ini KPKNL Batam memperkenalkan instansinya hanya melalui brosur, buku profil, banner, situs dan sosial media. Namun, masih sedikit informasi tentang KPKNL Batam dan juga informasi terkait layanan yang ada. Sehingga masyarakat umum jadi kurang mengetahui tugas dan fungsi serta layanan dari KPKNL Batam. Sementara terdapat layanan yang bisa digunakan oleh masyarakat umum seperti lelang dan penyewaan aset BMN.

Dengan adanya perkembangan teknologi penyampaian informasi khususnya media online seperti media sosial, website dan lainnya, sudah terdapat fasilitas untuk menjalankan media audio-visual. Melalui media audio memungkinkan untuk dapat menerima pesan pembelajaran melalui pendengaran, sedangkan unsur visual memungkinkan penciptaan pesan belajar melalui bentuk visualisasi [1]. Bentuk visualisasi dapat menggunakan objek 3D yang dinilai cukup berhasil dalam penyampaian informasi berupa profil perusahaan, disampaikan pada penelitian sebelumnya [2]. Selain itu, bentuk visualisasi dapat menggunakan video. Video merupakan suatu teknologi untuk menangkap pergerakan gambar dengan gelombang cahaya dan suara melalui sensor kameran dan mikrofon yang diubah menjadi sinyal elektromagnetik, kemudian diteruskan pada proses perekaman gambar bergerak menjadi suatu data dalam kesatuan gambar yang dapat dilihat secara berurutan dan kecepetan yang bervariasi [3]. Video dapat disebut sebagai gabungan gambar-gambar yang bergerak sehingga dapat menciptakan sebuah kesan serta menjadi media penyampaian pesan.

Salah satu media penyampaian informasi dari sebuah perusahaan atau lembaga/instansi, dapat melalui video company profile. Video company profile merupakan audio visual yang diproduksi untuk menciptakan image perusahaan. Video company profile digunakan untuk memperkenalkan perusahaan dan menginformasikan tentang keunggulan perusahaan [4]. Kelebihan company profile salah satunya dapat menerapkan audio-visual sehingga penyampaian informasi terhadap suatu instansi akan lebih mudah dipahami oleh penonton. Selain itu, isi pesan audio visual memiliki kekuatan yang sangat tinggi untuk mempengaruhi mental, pola pikir dan tindak individu [5].

Dalam penelitian ini, dibuat video company profile untuk menginformasikan KPKNL Batam menggunakan pendekatan Luther Sutopo. Dasar pemilihan metode ini karena memenuhi tiga kriteria yaitu tidak membentuk organisasi, tidak membahas pembiayaan, dan kesesuaian antara nama tahapan sesuai dengan proses atau kegiatan yang dikerjakan[6]. Video company profile yang dihasilkan, kemudian dianalisis kualitas dan kontennya. Kualitas video dianalisis berdasarkan dua aspek yaitu visual dan suara, sedangkan dari sisi konten akan dianalisis berdasarkan aspek materi yang sesuai dengan jasa dan layanan KPKNL. Pendekatan analisis menggunakan eksperimen jenis Quasi Experimental dengan model Nonequivalent Control Group Design [7]. Berdasarkan hasil penelitian menggunakan metode Quasi Experimental dengan rancangan Nonequivalent Control Group Design, berdasarkan penelitian sebelumnya dinyatakan bahwa terdapat pengaruh yang signifikan pada pencapaian kompetensi siswa dalam aspek pemahaman materi menggunakan audio visual [8].

Oleh karena itu, target yang diharapkan dari penelitian ini adalah menghasilkan sebuah company profile digital dalam bentuk video sebagai media informasi tentang layanan KPKNL, selanjutnya dapat diketahui kelayakan dan keefektifan video tersebut sebagai media informasi berdasarkan aspek audio-visual dan aspek konten.

\section{METODE PENELITIAN}

Pembuatan video company profile KPKNL menggunakan pendekatan Luther Sutopo. Analisis kualitas video menggunakan metode Skala Likert sedangkan analisis konten/materi menggunakan pendekatan metode Eksperimen jenis Quasi Experimental model Nonequivalent Control Group Design dengan pengolahan data uji-t. Tahapan penelitian seperti diilustrasikan pada Gambar 1. 


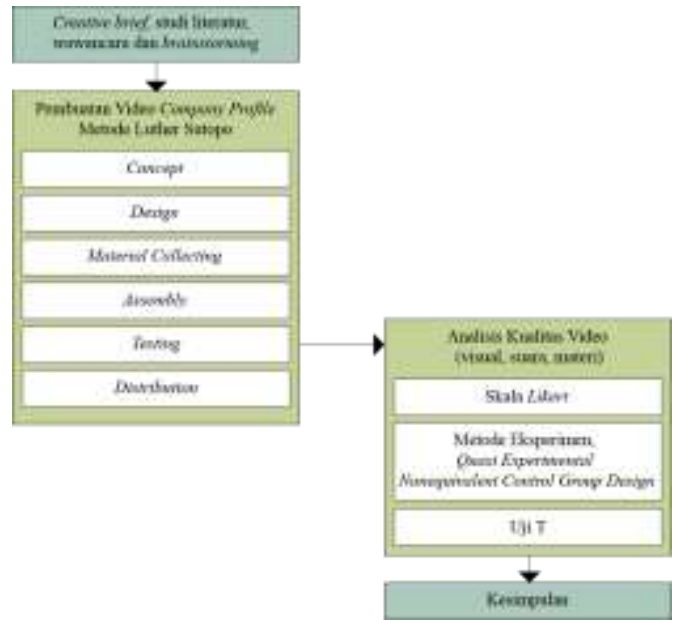

Gambar 1. Tahapan Penelitian Pembuatan dan Analisis Video Company Profile KPKNL

\subsection{Teknik Pengumpulan Data}

Teknik pengumpulan data dilakukan bertujuan untuk mendapatkan data atau informasi terkait perancangan video company profile. Beberapa pengumpulan data yang digunakan dalam penelitian ini antara lain, creative brief, studi literatur, wawancara dan brainstorming.

\section{1) Creative brief}

Creative brief merupakan data-data mengenai sebuah instansi yang nantinya data tersebut akan diolah menjadi materi untuk sebuah proyek. Dalam pembuatan video company profile KPKNL Batam, pengumpulan data diantaranya melalui buku profil, laporan tahunan serta berbagai hal mengenai keinginan dari pihak KPKNL Batam.

\section{2) Studi literatur}

Pada tahap ini studi literatur dilakukan untuk mencari referensi teori yang relevan dengan permasalahan yang ditemukan. Menggali informasi melalui buku, jurnal dan makalah.

3) Wawancara

Pengumpulan data juga dilakukan dengan cara wawancara kepada pihak KPKNL Batam untuk mendapatkan informasi atau data-data yang dibutuhkan. Melakukan wawancara tidak terstruktur dengan pihak KPKNL Batam diantaranya, kepala seksi dan pelaksana karena ingin mendapatkan informasi secara gambaran umum.

\section{4) Brainstorming}

Pada tahap ini, brainstorming dilakukan untuk mendapatkan ide/konsep dan beberapa hal pendukung lainnya. Dari brainstorming ini akan disortir data apa yang akan diolah untuk menjadi bahan pada video company profile.

\subsection{Pembuatan Video Company Profile KPKNL}

Metode Luther Sutopo terdiri dari enam tahap, yaitu yaitu konsep (concept), perancangan (design), pengumpulan materi (material collecting), pembuatan (assembly), pengujian (testing) dan distribusi (distribution). Keenam tahap ini tidak harus dikerjakan secara berurutan, namun untuk tahapan konsep merupakan hal pertama yang harus dikerjakan [6]. Proses tahapannya ditunjukkan pada gambar 2.

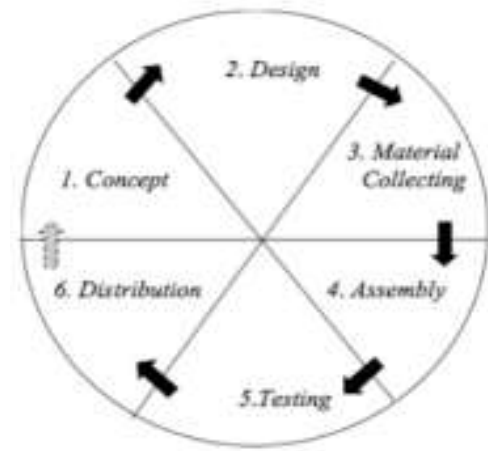

Gambar 2. Metode Pengembangan Multimedia versi Luther Sutopo

(Sumber: Iwan Binanto, 2015) 


\subsubsection{Konsep (concept)}

Tahapan ini bertujuan untuk menentukan jenis produk yang dibuat sesuai kebutuhan, tujuan serta target penonton. Konsep video yang dibuat disajikan pada tabel 1.

Tabel 1. Konsep Video Company Profile KPKNL

\begin{tabular}{|c|c|}
\hline Konsep & Keterangan \\
\hline Jenis Produk & Video company profile \\
\hline Tujuan & $\begin{array}{l}\text { Menyajikan informasi gambaran umum KPKNL dan } \\
\text { empat layanan utama sebagai media pengenalan dan } \\
\text { pemahaman KPKNL Batam } \\
\text { - Target pengguna: Instansi pemerintah, perbankan dan }\end{array}$ \\
\hline Karakteristik & \\
\hline Responden & $\begin{array}{l}\text { - Rentang usia: } 20-60 \text { tahun } \\
\text { - Berjenis kelamin perempuan dan pria }\end{array}$ \\
\hline Konten & Video, gambar, audio dan teks \\
\hline Format & $\begin{array}{l}\text { Gambar dalam format PNG/JPG. Rekaman suara, } \\
\text { backsound dan efek suara dalam format .MP3. Video } \\
\text { dalam format MP4. }\end{array}$ \\
\hline $\begin{array}{l}\text { Konsep Video } \\
\text { Company Profile }\end{array}$ & $\begin{array}{l}\text { Video company profile dibuat dengan konsep yang } \\
\text { tidak terlalu kaku, menyesuaikan dengan } \\
\text { perkembangan saat ini diantaranya menggunakan voice } \\
\text { over dengan nada bicara penyampaian yang tidak } \\
\text { formal karena dari pembuatan company profile KPKNL } \\
\text { wilayah lain mayoritas dijelaskan secara langsung oleh } \\
\text { narasumber. Pemilihan lagu upbeat sebagai backsound } \\
\text { video company profile. }\end{array}$ \\
\hline $\begin{array}{l}\text { Teknik } \\
\text { Pengambilan } \\
\text { Gambar dan } \\
\text { Video }\end{array}$ & $\begin{array}{l}\text { Teknik pengambilan gambar lebih dominan } \\
\text { menggunakan teknik still dengan menggunakan } \\
\text { bantuan tripod untuk meminimalisir hasil video yang } \\
\text { goyang atau tidak stabil. }\end{array}$ \\
\hline Durasi & 3 menit 50 detik \\
\hline Media Distribusi & Online melalui sosial media KPKNL Batam \\
\hline
\end{tabular}

\subsubsection{Perancangan (design)}

Pada tahap ini dijabarkan dengan rinci mengenai persiapan apa saja yang dibutuhkan. Mulai dari naskah, storyboard hingga spesifikasi perangkat keras dan perangkat lunak yang mendukung proses pra produksi, produksi, dan pasca produksi.

1) Naskah

Naskah yang digunakan dalam bentuk script untuk keperluan pengambilan gambar dan video serta digunakan oleh narator sebagai materi pengisian suara. Salah salah satu potongan naskah ditunjukkan pada gambar 3. 


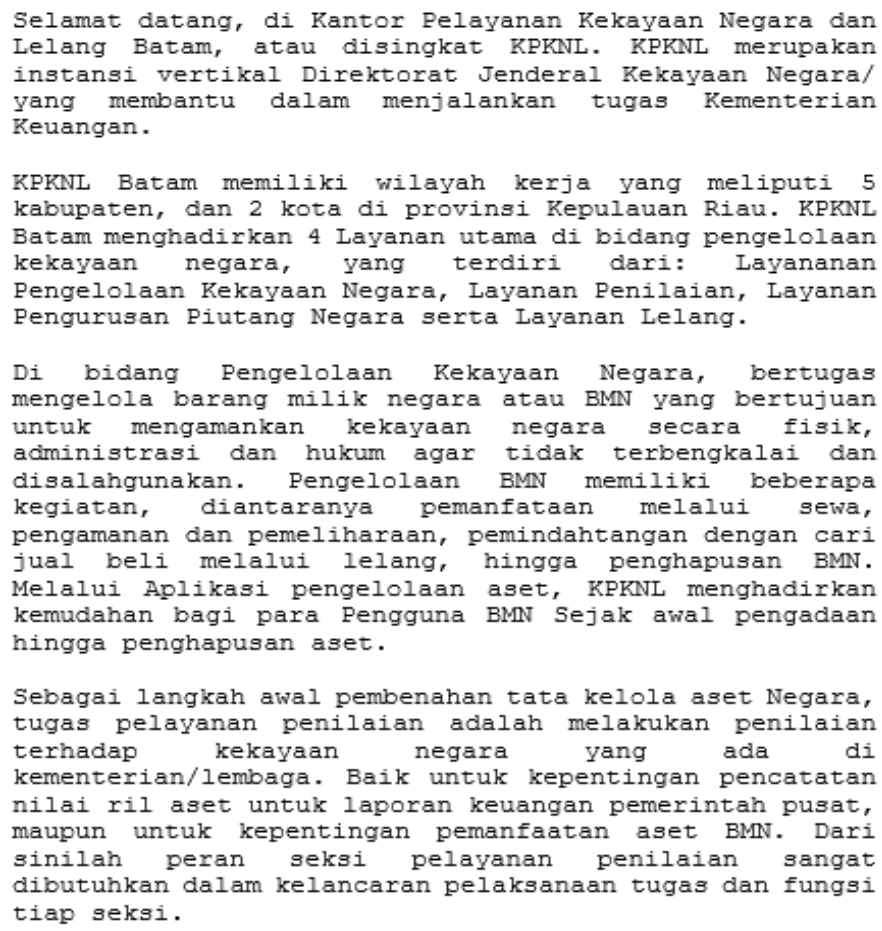

2) Storyboard

Gambar 3. Potongan Naskah Video Company Profile KPKNL

Storyboard digunakan untuk menjelaskan rencana produksi video dalam bentuk visual. Salah satu potongan storyboard yang digunakan seperti ditunjukan pada gambar 4 .

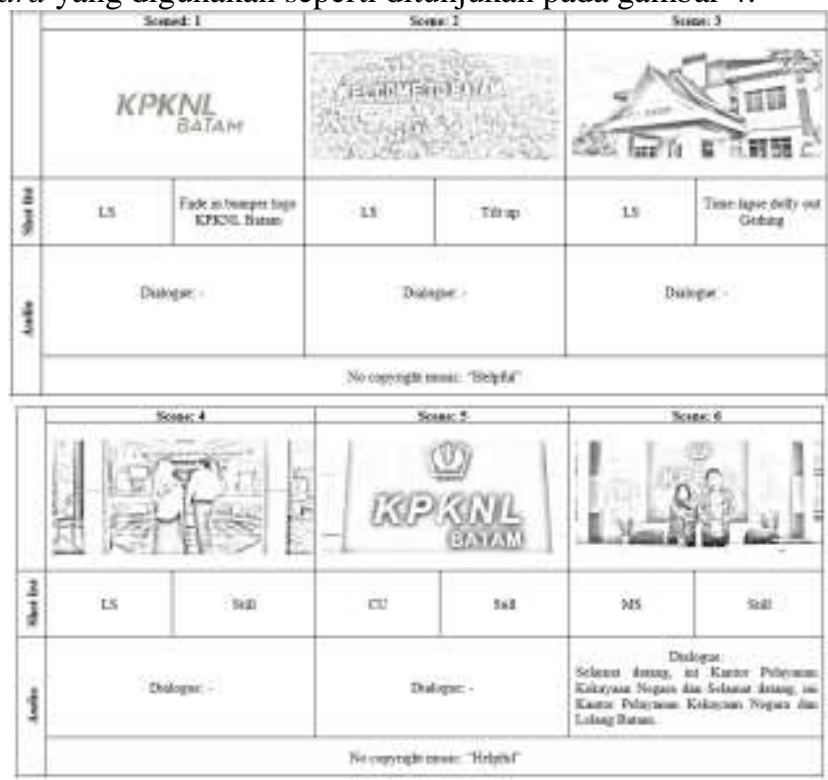

Gambar 4. Potongan Storyboard Video Company Profile KPKNL

\section{3) Spesifikasi Perangkat}

Spesifikasi perangkat yang digunakan dalam pembuatan video company profile KPKNL Batam terdiri dari perangkat keras (hardware) dan perangkat lunak (software) disajikan pada tabel 2.

Tabel 2. Spesifikasi Perangkat Produksi Video Company Profile KPKNL

\begin{tabular}{lll}
\multicolumn{1}{c}{ Nama } & \multicolumn{1}{c}{ Jenis Perangkat } & \multicolumn{1}{c}{ Spesifikasi } \\
\hline Workstation & Perangkat keras & Asus VivoBook Win 10 Core 15 \\
Hardisk & (hardware) & Toshiba 1 Tera \\
Kamera & & Sony a6300, Nikon, Canon 750D \\
Tripod & & Velborn
\end{tabular}


Lensa

Drone

Perekam Audio

Adobe Premiere Pro

Adobe After Effect

Adobe Media Encoder
Fix 50 1,8

DJI Phantom 4

Iphone 6 plus

Perangkat Lunak $\quad$ CC 2019

(Software) CC 2019

\subsubsection{Pengumpulan Materi (material collecting)}

Kegiatan pada tahap ini adalah melakukan eksekusi dari tahapan sebelumnya yaitu meliputi pengambilan gambar dan video, melakukan proses rekaman suara sesuai dengan naskah yang sudah dirancang. Mengumpulkan semua materi untuk video antara lain gambar, musik, efek suara dan lainnya seperti disajikan pada tabel 3 .

Tabel 3. Materi Video Company Profile

\begin{tabular}{ll}
\multicolumn{1}{c}{ Materi } & \multicolumn{1}{c}{ Keterangan } \\
\hline Gambar & Menggunakan gambar dokumentasi kegiatan yang didapatkan dari humas KPKNL Batam. \\
Video & Hasil rekaman dan dokumentasi perjalanan dinas \\
Musik & Menggunakan musik free copyright dengan judul helpful. (Youtube: MorningLightMusic) \\
Efek Suara & Menggunakan efek suara shutter. (Youtube: All Sounds) \\
Voice Over & Pengisi suara oleh Febria Hanum sesuai naskah \\
\hline
\end{tabular}

\subsubsection{Pembuatan (assembly)}

Pada tahap ini dilakukan proses penyuntingan mulai dari video hingga audio berdasarkan materi-materi yang sudah dikumpulkan pada tahap sebelumnya. Tahap penyuntingan terdiri dari dua tahapan yaitu editing offline dan online. Editing offline merupakan tahapan awal untuk menyeleksi file mentah (gambar dan video) yang digunakan. Sedangkan pada editing online dilakukan beberapa kegiatan antara lain:

1) Rough cut, yaitu menyatukan beberapa scene dan menyesuaikan dengan musik, voice over serta efek suara agar berkesinambungan.

2) Editing Subtitle, menambahkan caption/subtitle bahasa Indonesia sesuai dengan narasi.

3) Editing Color Grading, kegiatan ini melakukan keterpaduan warna (color grading) pada tiap gambar dan video untuk meningkatkan estetika dan kualitas dari video.

4) Rendering, kegiatan ini sebagai proses akhir editing online, yaitu melakukan rendering pada video company profile menggunakan aplikasi Adobe Media Encoder.

\subsubsection{Pengujian (testing)}

Pengujian dilakukan untuk meyakinkan bahwa semuanya sudah sesuai dengan rancangan dan tujuannya serta sesuai dengan keperluan pihak KPKNL Batam. Proses pengujian pada video company profile meliputi aspek kualitas visual dan suara serta tingkat pemahaman dalam aspek materi. Vaughan [9] memberikan dua tahapan yaitu pengujian alpha dan beta:

1) Pengujian alpha, merupakan pengujian awal yang dilakukan oleh yaitu tim pengembang dalam hal ini menguji kesesuaian rancangan dengan yang dihasilkan. Proses pengujian melibatkan pihak internal KPKNL Batam untuk mereview video sampai disetujui dan siap di distribusikan.

2) Pengujian beta, dilakukan untuk mengetahui persepsi dari responden umum di luar lingkungan tim pengembang terkait dengan aspek kualitas, visual dan suara serta materi video dari internal KPKNL Batam dan satuan kerja pemerintah mulai dari pemerintah pusat hingga daerah yang ada di Kepulauan Riau, perbankan serta masyarakat umum, melalui kuisioner online.

\subsubsection{Distribusi (distribution)}

Tahapan ini adalah menyimpan video company profile dalam media penyimpanan dan kemudian melakukan publikasi hasil video dengan beberapa media lain sesuai dengan keinginan dan ketentuan pihak KPKNL Batam. Hasil video yang didistribusikan menggunakan format MP4 dengan resolusi full high definition (FHD) 1920 x 1080 piksel berdurasi 3 menit 50 detik. Video company profile ini dapat diakses di sosial media KPKNL Batam antara lain instagram dan facebook.

\subsection{Metode Analisis Video Company Profile}

Pendekatan analisis yang digunakan adalah untuk mengetahui pendapat atau persepsi dari berbagai pihak berdasarkan aspek visual, suara dan konten/materi video. Pendekatan yang digunakan adalah Skala Likert dan 
metode Eksperimen yaitu Quasi Experimental dengan model Nonequivalent Control Group Design. Quasi Experimental bertujuan untuk mengungkapkan hubungan sebab akibat dengan cara melibatkan kelompok kontrol disamping kelompok eksperimen [7].

Instrumen penelitian yang digunakan untuk pengumpulan data berupa kuesioner menggunakan pengujian alpha dan beta. Pengujian alpha dilakukan pada responden yang merupakan tim pengembang dari internal KPKNL Batam. Sedangkan, pengujian beta dilakukan pada responden umum responden umum di luar lingkungan tim pengembang.

Penentuan sampling berdasarkan teknik Non-Probability Sampling (sampling purposive), yaitu adanya ketentuan untuk tidak memberi kesempatan yang sama bagi setiap anggota populasi untuk dipilih menjadi sampel [7]. Hal ini dikarenakan pengambilan sampel didasarkan pada pertimbangan tertentu, yaitu dua pengkategorian antara lain:

1) Pengujian aspek kualitas oleh pegawai, mulai dari kepala seksi hingga pelaksana serta Non PNS (pramubakti). Karakteristik responden berdasarkan jenis kelamin pria dan wanita dengan rentang usia antara 20-60 tahun.

2) Pengujian aspek materi, menggunakan pemangku kepentingan dari satuan kerja pemerintah dan perbankan sebagai kelompok kontrol. Sementara, pemangku kepentingan dari kategori non perbankan (swasta, lembaga lainnya dan masyarakat umum) sebagai kelompok eksperimen. Pengkategorian masyarakat umum tersebut berhubungan dengan layanan utama KPKNL Batam yaitu pengelolaan aset negara dari segi penyewaan aset BMN dan pelayanan lelang yang dapat dimanfaatkan oleh masyarakat umum. Karakteristik responden berdasarkan umur dan jenis kelamin yang sama dengan responden untuk pengujian aspek kualitas.

Ukuran sampel yang layak dalam penelitian menurut Roscoe dalam buku Research Methods for Business adalah antara 30 sampai dengan 500. Sementara untuk penelitian yang menggunakan kelompok eksperimen dan kelompok kontrol, dapat menggunakan jumlah sampel antara 10 s.d 20 [7]. Oleh sebab itu, pada penelitian ini jumlah responden yang digunakan adalah 20 responden untuk pengujian terhadap aspek kualitas dan 30 responden untuk pengujian terhadap aspek materi.

Pada penelitian ini, untuk mengetahui kualitas pada video company profile menggunakan pengukuran Skala Likert. Pengujian yang dimaksud dalam hal ini adalah untuk menggali respon dari responden terhadap video yang dihasilkan melalui kuesioner. Redaksi pernyataan yang digunakan disajikan pada tabel 4.

Tabel 4. Redaksi Pernyataan Terhadap Responden

\begin{tabular}{cll}
\hline No & Aspek & \\
\hline 1 & & Kesesuaian gambar dalam memvisualisasikan materi \\
2 & & Keterpaduan warna (color grading) \\
3 & Visual & Ukuran, jenis dan warna font pada video proporsional \\
4 & & Menggunakan berbagai sudut pengambilan gambar agar tidak monoton \\
5 & & Kesesuaian materi company profile dengan kebutuhan \\
6 & & Suara narator terdengar jelas \\
7 & & Istilah yang digunakan bersifat umum \\
8 & Suara & Pengunaan kata-kata mudah dipahami \\
9 & & Kesesuaian pemilihan suara/musik \\
10 & & Musik pengiring (backsound) lebih rendah dari suara dubber \\
\hline
\end{tabular}

Penentuan skor pada masing-masing pernyataan mengacu pada bobot Skala Likert seperti disajikan pada tabel 5 .

\begin{tabular}{lc}
\multicolumn{2}{c}{ Tabel 5. Tabel Bobot Skala Likert } \\
\hline \multicolumn{1}{c}{ Jawaban } & Bobot \\
\hline Sangat Setuju (SS) & 5 \\
Setuju (ST) & 4 \\
Ragu-ragu (RG) & 3 \\
Tidak Setuju & 2 \\
Sangat Tidak Setuju & 1 \\
\hline
\end{tabular}

Selain itu, untuk mengetahui perbandingan berdasarkan aspek materi yaitu pemahaman informasi sebelum dan sesudah ada video company profile digunakan t-test sampel related (uji-t dengan sampel berpasangan) untuk menguji ada tidaknya pengaruh dari pretest dan posttest yang diberikan. Bila sampel berkorelasi atau berpasangan, yaitu perbandingan sebelum dan sesudah perlakuan, atau perbandingan kelompok kontrol dengan kelompok eksperimen [7].

Penelitian dilakukan dengan menggunakan dua kelompok sampel, yaitu kelompok eksperimen (kelompok yang diberi perlakuan) dan kelompok kontrol (kelompok yang tidak diberi perlakuan). Analisis data dilakukan 
dengan perhitungan yang bertujuan untuk mengetahui ada tidaknya perbedaan yang signifikan antara pretest dan posttest pada kedua kelompok sampel. Apabila nilai kelompok eksperimen lebih tinggi dan signifikan dari kelompok kontrol, maka perlakuan yaitu menonton video company profile berpengaruh positif, bila memiliki hasil yang sama maka perlakuan tidak memiliki pengaruh, dan apabila hasil posttest lebih rendah dari nilai pretest, maka perlakuan berpengaruh negatif. Penelitian dilakukan dengan memberikan pretest dan posttest. Desain ini diilustrasikan seperti pada gambar 5.

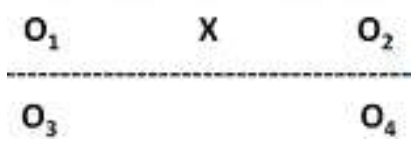

Gambar 5. Nonequivalent Control Group Design

\author{
Keterangan: \\ $\mathrm{O} 1$ dan $\mathrm{O} 3=$ Nilai pretest sebelum ada perlakuan \\ $\mathrm{O} 2=$ Nilai posttest setelah diberi perlakuan \\ $\mathrm{X} \quad=$ Perlakuan menonton video company profile \\ $\mathrm{O} 4 \quad=$ Nilai posttest yang tidak diberi perlakuan
}

Perbedaan nilai rata-rata hasil pretest-posttest masing-masing kelompok kontrol dan eksperimen dihitung dengan rumus Paired-sample T Test menggunakan program SPSS versi 17.0.

\section{HASIL DAN PEMBAHASAN}

\subsection{Hasil Implementasi Video Company Profile}

Produk yang dihasilkan dalam penelitian ini berupa video company profile yang diharapkan dapat dimanfaatkan sebagai media pengenalan KPKNL Batam. Video berisi tentang gambaran umum KPKNL Batam meliputi tugas dan fungsi empat layanan utama yang disajikan dengan konsep penyampaian informasi yang tidak kaku. Teknik yang digunakan dalam pengambilan gambar video company profile KPKNL Batam lebih dominan menggunakan teknik still dengan menggunakan bantuan tripod untuk meminimalisir hasil video yang goyang atau tidak stabil. Hal ini dikarenakan kurangnya sarana dalam hal stabilizer. Hal tersebut menjadi salah satu alasan pembuatan video company profile menggunakan teknik still. Still camera yaitu teknik pengambilan gambar dengan posisi kamera diam tidak bergerak, menghasilkan kedataran suasana adegan yang mengalir [8].

Bagian footage menggunakan drone dengan menampilkan ikon kota Batam dan beberapa footage dokumentasi yang diambil saat ada kegiatan di salah satu wilayah kerja KPKNL Batam. Rekaman suara dilakukan menggunakan Iphone 6 plus, karena kurangnya sarana seperti microphone pada perangkat audio. Sehingga pengalaman pengambilan gambar/video untuk kebutuhan video company profile ini sangat dipengaruhi oleh perangkat yang digunakan, terutama kamera, audio, drone dan lainnya. Berdasarkan hasil pengujian alpha, yang dilakukan pengembang untuk melihat kesesuaian rancangan dan review secara berulang oleh pihak dari KPKNL, sehingga pada tahap ini terjadi perbaikan untuk beberapa footage dan narasi. Namun, secara keseluruhan hasil video yang diimplementasikan sesuai rancangan awal baik naskah dan storyboard.

\subsection{Hasil Analisis Hasil Analisis Berdasarkan Aspek Kualitas Pada Video}

Analisis video terhadap kualitas berdasarkan aspek visual dan audio (suara), menggunakan 20 responden dari pihak internal KPKNL Batam yaitu pegawai, mulai dari kepala seksi hingga pelaksana serta Non PNS (pramubakti). Pengujian kualitas video company profile menggunakan skala likert. Jawaban skala likert mempunyai gradasi dari sangat positif hingga sangat negatif. Hasil pengujian terhadap aspek kualitas video disajikan pada tabel 6.

Table 6. Hasil Pengujian Berdasarkan Aspek Kualitas Video

\begin{tabular}{|c|c|c|c|c|c|c|c|}
\hline \multirow{2}{*}{$\begin{array}{l}\mathrm{N} \\
\mathrm{O}\end{array}$} & \multirow{2}{*}{ Aspek } & \multirow{2}{*}{ Indikator } & \multicolumn{5}{|c|}{ Jumlah Respon } \\
\hline & & & SS & $\mathrm{S}$ & RG & TS & STS \\
\hline 1 & \multirow{5}{*}{ Visual } & Kesesuaian gambar dalam memvisualisasikan materi & 17 & 3 & 0 & 0 & 0 \\
\hline 2 & & Keterpaduan warna (color grading) & 18 & 2 & 0 & 0 & 0 \\
\hline 3 & & Ukuran, jenis dan warna font pada video proporsional & 19 & 1 & 0 & 0 & 0 \\
\hline 4 & & $\begin{array}{l}\text { Menggunakan berbagai sudut pengambilan gambar agar tidak } \\
\text { monoton }\end{array}$ & 19 & 1 & 0 & 0 & 0 \\
\hline 5 & & Kesesuaian materi company profile dengan kebutuhan & 19 & 1 & 0 & 0 & 0 \\
\hline 6 & \multirow{5}{*}{ Suara } & Suara narator terdengar jelas & 20 & 0 & 0 & 0 & 0 \\
\hline 7 & & Istilah yang digunakan bersifat umum & 18 & 2 & 0 & 0 & 0 \\
\hline 8 & & Pengunaan kata-kata mudah dipahami & 18 & 2 & 0 & 0 & 0 \\
\hline 9 & & Kesesuaian pemilihan suara/musik & 20 & 0 & 0 & 0 & 0 \\
\hline 10 & & Musik pengiring (backsound) lebih rendah dari suara dubber & 20 & 0 & 0 & 0 & 0 \\
\hline
\end{tabular}

JAMN Vol. 4, No. 2, Desember 2020 
Berdasarkan data pada tabel 6, maka dihitung jawaban berdasarkan skor setiap jawaban dari 20 responden. Untuk menghitung jumlah skor tertinggi menggunakan rumus:

Skor Terting gi $=$ Skor tertinggi $*$ jumlah butir pernyataan $*$ jumlah responden

Berdasarkan rumus tersebut diperoleh skor sebesar 988 atau 98,80\% secara rinci disajikan pada tabel 7.

Table 7. Hasil Persentase Pengujian Terhadap Aspek Kualitas Video

\begin{tabular}{|c|c|c|c|c|}
\hline No & Aspek & Indikator & Total Skor & Persentase \\
\hline 1 & \multirow{4}{*}{ Visual } & Kesesuaian gambar dalam memvisualisasikan materi & 97 & $97 \%$ \\
\hline 2 & & Keterpaduan warna (color grading) & 98 & $98 \%$ \\
\hline 3 & & Ukuran, jenis dan warna font pada video proporsional & 99 & $99 \%$ \\
\hline 4 & & $\begin{array}{l}\text { Menggunakan berbagai sudut pengambilan gambar } \\
\text { agar tidak monoton }\end{array}$ & 99 & $99 \%$ \\
\hline 5 & \multirow{7}{*}{ Suara } & Kesesuaian materi company profile dengan kebutuhan & 99 & $99 \%$ \\
\hline 6 & & Suara narator terdengar jelas & 100 & $100 \%$ \\
\hline 7 & & Istilah yang digunakan bersifat umum & 98 & $98 \%$ \\
\hline 8 & & Pengunaan kata-kata mudah dipahami & 98 & $98 \%$ \\
\hline 9 & & Kesesuaian pemilihan suara/musik & 100 & $100 \%$ \\
\hline 10 & & $\begin{array}{l}\text { Musik pengiring (backsound) lebih rendah dari suara } \\
\text { dubber }\end{array}$ & 100 & $100 \%$ \\
\hline & & Rata-rata Hasil Pengujian & 988 & $\mathbf{9 8 , 8 0 \%}$ \\
\hline
\end{tabular}

Dari hasil pada tabel 7, maka berdasarkan range nilai skala Likert STS hingga SS dengan rentang nilai 200 hingga 1000, maka diperoleh nilai rata-rata 988 termasuk dalam kategori interval "setuju dan sangat setuju”. Tetapi lebih mendekati sangat setuju. Secara kontinum dapat digambarkan seperti pada gambar 6.

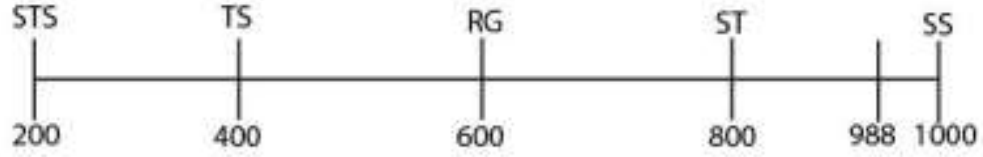

Gambar 6. Nilai Rata-rata Pengujian Video secara Kontinum

Dengan demikian dapat disimpulkan, kualitas video company profile yang dihasilkan memiliki kualitas yang baik dilihat dari aspek visual dan suara dengan sepuluh indikator penilaian, sehingga video company profile dinilai dapat menyajikan informasi mengenai KPKNL Batam dengan jelas dan menarik kepada pengguna.

\subsection{Hasil Analisis Berdasarkan Aspek Materi Pada Video}

Pengumpulan data dari aspek materi diperoleh dari penggalian informasi dari responden sebelum dan sesudah menggunakan video company profile. Pengumpulan data dilakukan melalui pengujian secara online dengan jumlah 10 soal pretest dan posttest berupa pilihan ganda. Pengujian berdasarkan aspek materi ini untuk mengetahui pengaruh video terhadap pengenalan dan pemahaman responden tentang informasi secara gambaran umum dan layanan KPKNL.

Pengolahan data menggunakan Uji-t untuk mengukur perbedaan rata-rata hasil pengujian sebelum (pretest) dan sesudah (posttest) menggunakan video company profile. Jumlah responden terdiri dari 15 responden kelompok eksperimen dan 15 kelompok kontrol. Dari hasil statistik data yang diperoleh berupa ratarata nilai pretest dan posttest dari dua kelompok sampel yaitu kelompok kontrol dan eksperimen, seperti ditunjukkan pada gambar 7 . 


\begin{tabular}{|c|c|c|c|c|c|}
\hline \multicolumn{6}{|c|}{ Paired Samples Statistics } \\
\hline & & Mean & $N$ & Std. Deviation & $\begin{array}{l}\text { Std. Error } \\
\text { Mean }\end{array}$ \\
\hline \multirow[t]{2}{*}{$\overline{\text { Pair } 1}$} & $\begin{array}{l}\text { Score Pretest Kelompok } \\
\text { Control }\end{array}$ & 56.67 & 15 & 17.593 & 4.543 \\
\hline & $\begin{array}{l}\text { Score Posttest Kelompok } \\
\text { Control }\end{array}$ & 50.67 & 15 & 16.242 & 4.194 \\
\hline \multirow[t]{2}{*}{ Pair 2} & $\begin{array}{l}\text { Score Pretest Kelompok } \\
\text { Eksperimen }\end{array}$ & 38.00 & 15 & 14.243 & 3.677 \\
\hline & $\begin{array}{l}\text { Score Posttest Kelompok } \\
\text { Eksperimen }\end{array}$ & 73.33 & 15 & 11.127 & 2.873 \\
\hline
\end{tabular}

Gambar 7. Hasil pengujian Paired Samples Statistics

Penjelasan pada output pertama pada gambar 7 adalah:

1) Nilai pretest kelompok kontrol diperoleh nilai rata-rata sebesar 56,67 sedangkan untuk hasil posttest diperoleh nilai rata-rata sebesar 50,67.

2) Nilai pretest kelompok eksperimen diperoleh nilai rata-rata sebesar 38,00 sedangkan hasil posttest setelah diberikan perlakuan menonton video company profile diperoleh nilai rata-rata sebesar 73,33.

Terjadi penurunan nilai rata-rata antara pretest $56.67>$ posttest 50.67 pada kelompok kontrol dikarenakan tidak ada perlakuan yang diberikan. Sedangkan pada kelompok eksperimen yakni nilai pretest $38.00<73.33$ posttest. Maka terdapat peningkatan rata-rata setelah diberi perlakuan menonton video company profile pada kelompok eksperimen.

Selanjutnya untuk membuktikan apakah peningkatan tersebut signifikan atau tidak akan ditunjukan dengan hasil uji korelasi. Hasil output kedua adalah korelasi antara kedua variabel sampel kedua kelompok yang menampilkan jumlah sampel sebanyak masing-masing 15, dengan nilai koefisien korelasi (correlation) kelompok kontrol sebesar 0,783 dan nilai signifikansi (Sig) sebesar 0,001, sedangkan untuk kelompok eksperimen nilai korelasi sebesar -0,315 dan nilai signifikansi 0,252. Ringkasan output kedua dapat dilihat pada gambar 8 .

Paired Samples Correlations

\begin{tabular}{|cl|r|r|r|}
\hline & \multicolumn{1}{|c|}{$N$} & Correlation & \multicolumn{1}{c|}{ Sig. } \\
\hline Pair 1 & $\begin{array}{l}\text { Score Pretest Kelompok } \\
\text { Control \& Score Posttest } \\
\text { Kelompok Control }\end{array}$ & 15 & .783 & .001 \\
Pair 2 & $\begin{array}{l}\text { Score Pretest Kelompok } \\
\text { Eksperimen \& Score } \\
\text { Posttest Kelompok } \\
\text { Eksperimen }\end{array}$ & 15 & -.315 & .252 \\
\hline
\end{tabular}

Gambar 8. Hasil pengujian Paired Samples Correlations

Berdasarkan output nilai koefisien (correlations, ) nilai sig. kelompok kontrol sebesar $0.001<0.05$, maka tidak ada peningkatan rata-rata antara pretest dan posttest. Sedangkan output nilai sig kelompok eksperimen sebesar $0.252>0.05$, maka terdapat peningkatan rata-rata antara pretest dan posttest. Hal ini menyatakan bahwa korelasi antara sebelum dan sesudah menonton video company profile memiliki hubungan yang signifikan.

Pada output ketiga merupakan tahapan untuk pengambilan kesimpulan. Menggunakan peluang kesalahan 5\% dan taraf kepercayaan 95\%. Berdasarkan tabel output "paired samples test", nilai t hitung kelompok kontrol 2.073, sedangkan nilai thitung kelompok eksperimen bernilai -6.626. Nilai thitung bernilai negatif karena nilai rata-rata hasil pretest lebih rendah dari posttest. Dalam konteks tersebut, nilai t hitung negatif dapat bermakna positif [10]. Ringkasan output dapat dilihat pada gambar 9. 


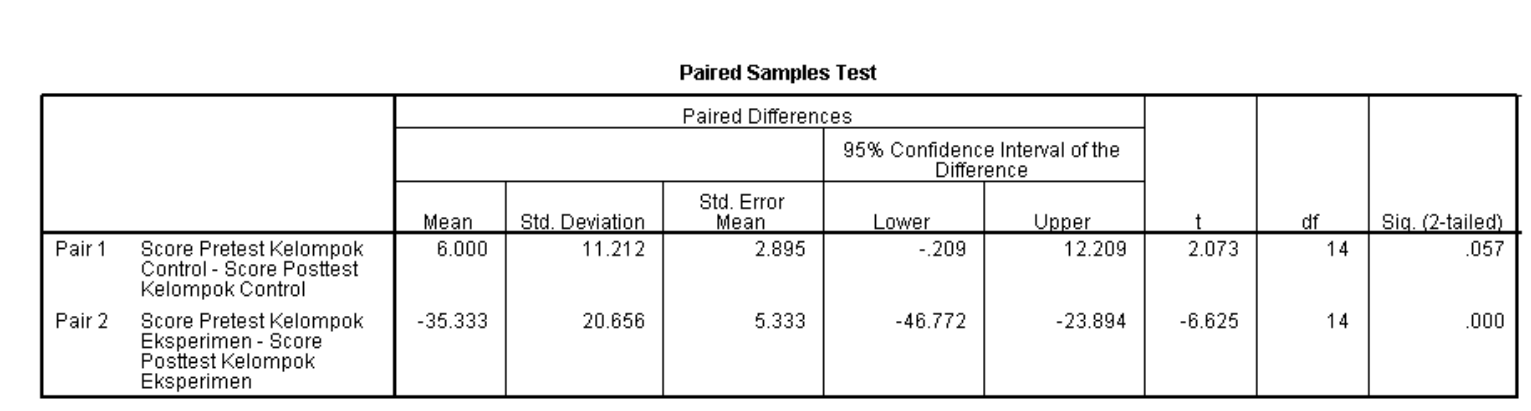

Gambar 9. Hasil pengujian Paired Samples Test

Rumusan hipotesis dalam penelitian ini adalah:

Ho = Tidak ada peningkatan rata-rata antara pretest dan posttest artinya video company profile tidak berpengaruh atau tidak efektif dalam penyampaian materi pengenalan dan pemahaman KPKNL Batam.

$\mathbf{H a}=$ Ada peningkatan rata-rata antara pretest dan posttest yang artinya video company profile berpengaruh atau efektif dalam penyampaian materi pengenalan dan pemahaman KPKNL Batam.

Dasar pengambilan keputusan dalam uji paired sample t-test menurut Singgih Santoso dapat berdasarkan nilai probabilitas. Jika probabilitas $>\mathbf{0 , 0 5}$, maka Ho diterima. Jika probabilitas $<0,05$, maka Ho. Ditolak [11].

Berdasarkan hasil uji sampel berpasangan pada gambar 9, dapat disimpulkan bahwa:

1) Kelompok kontrol dengan nilai Sig. (2-tailed) sebesar 0,057>0,05, maka Ho diterima dan Ha ditolak.

2) Kelompok eksperimen dengan nilai Sig. (2-tailed) sebesar 0,000 < 0,05, maka Ho ditolak dan Ha diterima.

Sehingga dapat disimpulkan bahwa terdapat perbedaan rata-rata antara sebelum dan sesudah menggunakan video pada kelompok eksperimen, yang artinya video company profile berpengaruh atau efektif dalam penyampaian materi untuk pengenalan dan pemahaman KPKNL Batam bagi pemangku kepentingan atau masyarakat umum.

\section{KESIMPULAN}

Berdasarkan hasil dan pembahasan yang diuraikan, beberapa kesimpulan penelitian ini adalah:

1) Rancang bangun video company profile KPKNL Batam menghasilkan video dalam format MP4 dengan durasi 3 menit 50 detik dan dapat dijalankan dalam berbagai media serta dapat diakses secara online di sosial media KPKNL Batam salah satunya Instagram.

2) Video company profile telah diuji berdasarkan aspek kualitas visual dan suara menggunakan skala Likert dengan hasil presentasi mencapai $98,80 \%$, sehingga video ini dinilai memiliki kualitas yang baik dan layak untuk memberikan informasi kepada pemangku kepentingan.

3) Video company profile dinilai efektif sebagai media informasi berdasarkan aspek konten atau materi tentang layanan KPKNL Batam bagi pemangku kepentingan melalui hasil uji-t kelompok eksperimen dengan nilai signifikan sebesar 0,000 yang lebih kecil dari nilai probabilitas $=0,05$.

4) Produksi video dapat dipengaruhi oleh perangkat, sehingga direkomendasikan untuk mengemas informasi dan layanan yang lebih spesifik dan rinci di KPKNL Batam. 


\section{UCAPAN TERIMA KASIH}

Puji syukur diucapkan kepada Allah SWT atas segala rahmat dan karunia-NYA sehingga dapat menyelesaikan tugas akhir yang berjudul "Rancang Bangun dan Analisis Video Company Profile (Studi Kasus: Kantor Pelayanan Kekayaan Negara dan Lelang Batam)". Adapun tujuan penulisan tugas akhir ini sebagai salah satu persyaratan untuk menyelesaikan Studi Diploma IV Teknik Multimedia dan Jaringan di Politeknik Negeri Batam. Dalam menyelesaikan pembuatan produk dan penyusunan tugas akhir, tidak terlepas dari banyak pihak yang telah membantu, membimbing dan mendukung. Untuk itu, diucapkan terimakasih yang sebesar-besarnya kepada kedua orang tua dan keluarga yang selalu memberikan doa dan dukungannya. Bapak Sumarsono selaku Kepala Kantor KPKNL Batam yang telah memberikan izin produksi dan seluruh pihak internal KPKNL Batam yang telah membantu dan membimbing. Tim pengembang company profile, Bang Arief, Bang Janes, dan Bang Furqon yang telah banyak membantu. Bang Achmad Revai Yahya, Politeknik Negeri Batam dan KPKNL Batam dan lainnya yang telah meminjamkan sarana selama kegiatan produksi. Dalam menyusun laporan proyek industri ini masih memiliki kekurangan. Oleh karena itu kritik dan saran sangat diterima untuk perbaikan yang lebih baik.

\section{DAFTAR PUSTAKA}

[1] N. H. Waryanto, "Penggunaan Media Audio Visual dalam Menunjang Pembelajaran," 2007.

[2] R. Hidayat, H. Gunawan, dan D. Susandi, "Pembuatan Video Profil Perusahaan Berbasis Animasi 3D Di Pt. Krakatau Insan Mandiri,” J. SIMIKA, vol. 2, no. 1, hal. 64-80, 2019.

[3] F. H. Fariskha, "Pembuatan Video Features Tentang Engklek Dan Congklak Dengan Teknik Cut Away Sebagai Upaya Pelestarian Permainan Tradisional Di Kota Surabaya,” Institut Bisnis dan Informatika STIKOM Surabaya, 2016.

[4] I. M. Alif, "Perancangan Video Company Profile Pt. Pembangkitan Jawa-Bali Investasi Sebagai Kerja Praktik," Surabaya, 2017.

[5] A. Komari, F. D. Andriyani, dan E. S. Kriswanto, "Pengembangan Company Profile Prodi PJKR Jurusan POR FIK UNY Berbasis Audio Visual,” Yogyakarta, 2014.

[6] I. Binanto, "Tinjauan Metode Pengembangan Perangkat Lunak Multimedia Yang Sesuai Untuk Mahasiswa Tugas Akhir," Semin. Nas. Rekayasa Komput. dan Apl., hal. 148-155, 2015.

[7] Sugiyono, Metode Penelitian Kuantitatif Kualitatif dan R\&D, Kedua. Bandung: Alfabeta, 2019.

[8] E. Purnawati dan M. Suyanto, "Perancangan Periklanan Multimedia dengan Teknik Sinematografi untuk Program Publikasi (Studi Kasus: Disporabudpar Kabupaten Banyumas),” Telematika, vol. 9, no. 1, hal. 15-26, 2016.

[9] I. Binanto, "Perbandingan Metode Pengembangan Perangkat Lunak Multimedia," J. Ilm. Sains dan Teknol., vol. 16, no. 1, hal. 1-7, 2014.

[10] S. Raharjo, "Cara Uji Paired Sample T-Test dan Interpretasi dengan SPSS,” SPSS Indonesia, 2014. [Daring]. Tersedia pada: https://www.spssindonesia.com/2016/08/cara-uji-paired-sample-t-testdan.html?m=1. [Diakses: 30-Jul-2020].

[11] S. Santoso, Panduan Lengkap SPSS Versi 23, Pertama. Jakarta: PT Elax Media Komputindo, 2016. 